\title{
Topçam Tüneli Deformasyonlarının Rastgele Küme Sonlu Elemanlar Yöntemi İle Hesaplanması
}

\author{
Erhan TEKİN ${ }^{\mathrm{a}}$, Gamze DÖNDER ${ }^{*}, \mathrm{a}$, Nail ÜNSAL ${ }^{\mathrm{a}}$, \\ a,* Gazi Üniversitesi Mühendislik Fakültesi Inşaat Mühendisliği Bölümü, ANKARA 06500, TÜRKİYE
}

\section{MAKALE BİLGİSi}

Alınma:08.04.2019 Kabul: 30.06.2019

\section{Anahtar Kelimeler: \\ Tünel, Rastgele Küme \\ Sonlu Elemanlar \\ Yöntemi, \\ Deformasyon, Topçam \\ Tüneli \\ *Sorumlu Yazar: \\ e-posta: \\ celliade89@gmail.com}

\section{ÖZET}

\begin{abstract}
$\mathrm{Bu}$ çalışmada rastgele küme sonlu elemanlar metodu ile elde edilen tünel deformasyon sonuçlarının arazi ölçümleriyle karşılaştırılması amaçlanmıştır. Çalışma için Ordu ili Ulubey ilçesinde bulunan Topçam tüneli 35+192 km kesiti seçilmiştir. Tünel 2 boyutlu sonlu elemanlar yöntemi ile modellenmiş ve Mohr-Columb kriterleri kullanılarak kaya parametreleri modele tanımlanmıştır. Elastisite modülü, kohezyon, içsel sürtünme açısı ve rahatlama faktörü parametrelerinin üst ve alt limit aralıkları iki ayrı küme halinde belirlenmiștir. Değişkenleri iki kümeye ayırma işleminde laboratuvar, arazi çalışmaları ve literatür bilgisi kullanılmıştır. Her bir kümedeki elastisite modülü, kohezyon, içsel sürtünme açısı ve rahatlama faktörü değerlerinin kendi aralarında kartezyen çarpımı yapılarak 256 ayrı kombinasyon oluşturulmuştur. Elde edilen analiz sonuçlarından tüneldeki 5 nokta için deformasyonların olasılıksal dağılım grafikleri teşkil edilmiştir. Topçam tüneli için sahada yapılan deformasyon ölçümleri ile olasılıksal dağılım grafiğinden elde edilen sonuçlar karşılaştırılmıştır. Bu karşılaştırmanın sonucunda olasılıksal dağılım grafiğindeki maksimum ve minimum aralıkların saha ölçümleri ile uyumlu olduğu görülmüştür.
\end{abstract}

\section{Analysis Of Topcam Tunnel Deformations By Random Set Finite Element Method}

\section{ARTICLE} INFO

Received: 08.04.2019 Accepted: 30.06 .2019

\section{Keywords:}

Tunnel, Random Set

Finite Element

Method, Deformation,

Topcam Tunnel

$\frac{\text { Corresponding }}{\text { Authors }}$
e-mail:
celliade89@gmail.com

ABSTRACT

In this study it's aimed that comparing field measurements with tunnel deformation results which are obtained by using random set of finite element method. Topcam tunnel is located Ulubey, Ordu and this tunnel's section between 35 and $192 \mathrm{~km}$ is chosen for this study. Tunnel is modeled by using 2 dimension finite element method and rock parameters are defined to the model by using Mohr- Coulomb criteria. The parameters of elasticity module, cohesion, internal friction angle and relaxation factors upper and lower limit ranges are determined in two separate sets. Lab, field studies and literature knowledge is used for separating variables in two sets. The elasticity module, cohesion, internal friction angle and relaxation factor parameters of in each cluster are produced 256 combinations with Cartesian multiplied among themselves. Probability distribution graphs of deformation for 5 spots in the tunnel are established with the help of obtained analysis results. Deformation measurements of field study and probability distribution graph results are compared for Topcam tunnel. As a result of this comparison its acquired that the probability distribution graph's maximum and minimum ranges conform with field studies. 


\section{GIRISS ( INTRODUCTION)}

Tünellerde deformasyon, tünelin açılmasıyla gelişen yeni şartlarla birlikte tünelin üzerine etkiyen gerilmelerin yeniden dağıllım göstermesiyle oluşmaktadır. Deformasyonu etkileyen başlıca unsurlar kayanın özellikleri, tünel açım yöntemi ve kemerlenme etkisidir. Arazi ve laboratuvar deneylerinden elde edilen veriler kaya parametrelerini sınırlı oranda temsil etmektedir. Parametrelerin belirlenmesinde ölçüm hataları, dönüşüm belirsizlikleri ile kayanın doğasındaki belirsizlikler etkili olabilmektedirler. Birinci belirsizlik, ekipman, yöntem, operatör ve rastgele test etme etkilerinden; ikinci belirsizlik, laboratuvar veya arazi deney sonuçlarını ampirik ve diğer korelasyonlarla zemin tasarım özelliklerine çevrilmesinden; üçüncü belirsizlik ise zemin formasyonunun özelliğinde olan doğal jeolojik süreçten kaynaklanır [1].

Yukarıda bahsedilen belirsizliklerin üstesinden gelmek için olasılıksal yöntemler kullanılmaktadır. Başlangıçta olasılıksal metodlar, rastgele küme sonlu küme teorisi olarak Dempster (1967) [2], Kendall (1974) [3], Shafer (1976) [4] ve Dubois (1991) [5] gibi birçok çalışmacı tarafından geliştirilmiştir. Bu çalışmacılar klasik olasılık teorisinin bazı dezavantajlarının üstesinden gelmek amaciyla uygun bir matematiksel model sağlamıştır. Peschl (2004) [6] ve Schweiger ve Pechl (2007) [7] yaptıkları çalışmalarla rastgele küme teorisi ile sonlu elemanlar metodunu birleştirerek rastgele küme sonlu elemanlar metodunu oluşturmuşlardır.

Schweiger ve Pechl (2007) [7] ve Nasekhian ve Schweiger (1998) [8] çalışmaları tünel üzerinde yapılmış olan rastgele küme sonlu elemanlar yöntemi uygulamalarına öncü olmuştur. Model girdi parametrelerinin olasılıksal dağılımını dikkate alarak sonlu elemanlar yöntemiyle deterministik çözüm sunmuşlardır. Rastgele küme teorisi yardımıyla elde ettikleri sonuçları sahada bulunan ölçüm sonuçları ile karşılaştırmışlar ve yöntemin uygulanabilir olduğunu ortaya koymuşlardır.

$\mathrm{Bu}$ çalışmada ise bir tünelin rastgele küme sonlu elemanlar metodu ile modellemesi yapılmıştır. Elastisite modülü, kohezyon, içsel sürtünme açısı ve rahatlama faktörü değişken parametre olarak kabul edilmiştir. $\mathrm{Bu}$ parametreler kullanılarak 256 adet kombinasyon oluşturulmuș ve her biri için deformasyon hesaplaması yapılmıştır. Saha ölçümleri ile hesaplanan deformasyon değerleri karşılaştırılmıştır.

\section{TEORİK METHOD (THEORETICAL METHOD)}

\subsection{Uygulama Yeri (Application Location)}

Çalışma alanı için Ordu ili, Ulubey ilçesine bağlı Topçam Beldesi sınırları içerisinde yer alan Topçam Tüneli seçilmiştir (Şekil 1). Tünel, T1 ve T2 olmak üzere iki adet tek tüplü karayolu tüneli olarak planlanmıştır. Tünel genelinde sağlam dayanımlı, az çatlaklı siyenit birimin bulunduğu belirlenmiştir. Sayısal modelleme çalışması T1 tüneli $35+192 \mathrm{~km}$ kesitinde yapılmıştır. Tünel derinliği (H) $32 \mathrm{~m}$, tünel çapı (R) ise 7,0 m'dir (Şekil 2, Şekil 3).

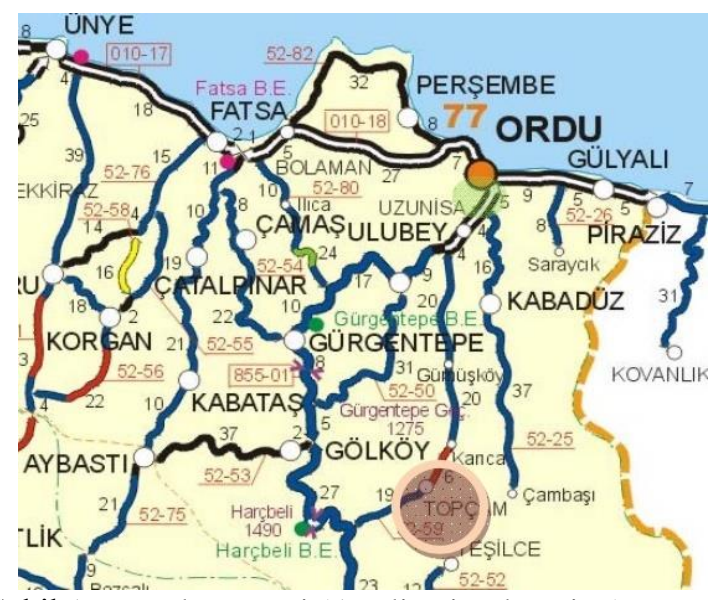

Şekil 1. Uygulama yeri (Application location)

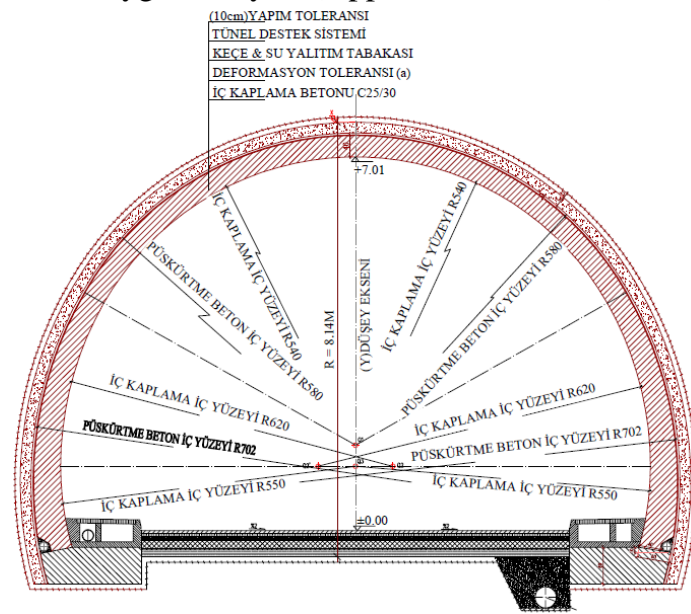

Şekil 2. T1 tüneli km: 35+192'ye ait enkesit görünüşü (T1 tunnel km:35+192's cross-section view) 


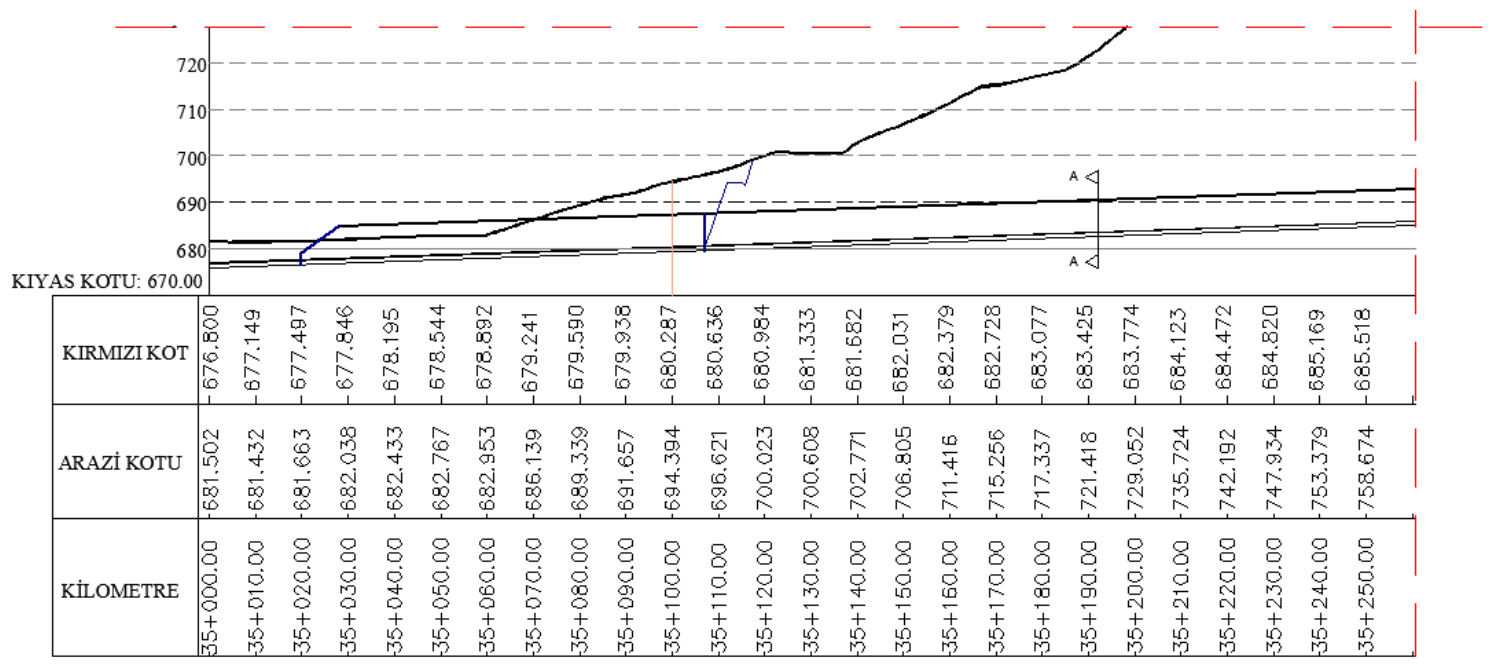

Şekil 3. Tünelin boy kesiti (Section view of tunnel )

\subsection{Uygulama Yeri Deformasyon Ölçümleri (Deformation Measurements of Application Area)}

Tünelde Şekil 4'te gösterilen tavan ve yan duvarlarda bulunan 5 nokta üzerinden, tünel içi yatay ve düşey deformasyon ölçümü jeodezik olarak alınmıştır. Noktalara ait bir önceki ölçümler ile bir sonraki ölçümler arasındaki koordinat farklarından deformasyon vektörü saptanmıştır (Eş. (1)).

$d_{i}=\sqrt{d_{x, i}^{2}+d_{y, i}^{2}+d_{z, i}^{2}}$

Deformasyon vektörü ortalama hataya bölünerek t-dağılımında \%95 güven aralığında anlamlı olan değerler hesaplanmıştır (Niemeier, 1981, [9]).Tablo 1 'de bu noktalara ait deformasyon ölçümlerinin minimum ve maksimum değerleri verilmiştir.

Tablo 1. Deformasyon okumaları (Deformation readings)

\begin{tabular}{|l|c|c|c|c|c|}
\hline \multicolumn{1}{|c|}{ Nokta No } & 1 & 2 & 3 & 4 & 5 \\
\hline $\begin{array}{l}\text { Minimum } \\
\text { yatay } \\
\text { deformasyon } \\
(\mathrm{mm})\end{array}$ & 1,00 & 1,00 & 1,20 & 0,60 & 1,00 \\
\hline $\begin{array}{l}\text { Maksimum } \\
\text { yatay } \\
\text { deformasyon } \\
\text { (mm) }\end{array}$ & 6,00 & 5,40 & 8,00 & 3,00 & 3,00 \\
\hline $\begin{array}{l}\text { Minimum } \\
\text { düşey } \\
\text { deformasyon } \\
\text { (mm) }\end{array}$ & 2,32 & 0,50 & 0,84 & 0,20 & 0,40 \\
\hline $\begin{array}{l}\text { Maksimum } \\
\text { düşey } \\
\text { deformasyon } \\
\text { (mm) }\end{array}$ & 10,27 & 3,76 & 6,76 & 1,39 & 3,50 \\
\hline
\end{tabular}

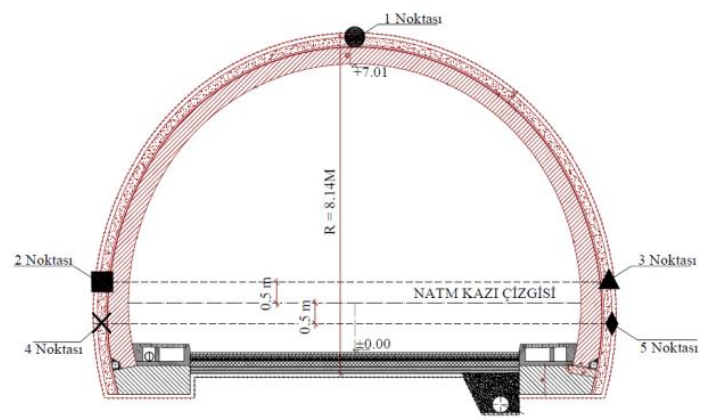

Şekil 4. Deformasyon ölçüm noktaları (Deformation measurement points)

\subsection{Kaya Parametreleri (Rock Parameters)}

Sonlu elemanlar modelinde kaya davranışı MohrCoulomb yenilme kriterleri ile modellenmiştir. Mohr-Coulomb modelinin parametreleri HoekBrown sinıflandırma parametrelerinden hesaplanmaktadır. Tek eksenli basınç dayanımı $\left(\sigma_{\text {ci }}\right)$, jeolojik dayanım indeksi (GSI), kaya malzemesi katsayısının indirgenmiş değeri $\left(\mathrm{m}_{\mathrm{i}}\right)$, örselenme faktörü (D) ve modül oranı (MR) değerlerine bağlı olarak kohezyon (c), içsel sürtünme açısı $(\phi)$ ve deformasyon modülü $\left(\mathrm{E}_{\mathrm{rm}}\right)$ bulunmaktadır.

Laboratuvar çalışmalarından yenilme durumunda maksimum asal gerilme $\left(\sigma_{1 \mathrm{f}}\right) 487,50 \mathrm{MPa}$,minimum asal gerilme $\left(\sigma_{3 \mathrm{f}}\right) 8,24 \mathrm{MPa}$, maksimum tek eksenli basınç dayanımı $\left(\sigma_{\text {ci(mak })}\right) 67,54 \mathrm{MPa}$, minimum tek eksenli basınç dayanımı $\left(\sigma_{\text {ci(min) }}\right) 20,80 \mathrm{MPa}$, doğal birim hacim ağırlık $(\gamma) 27 \mathrm{kN} / \mathrm{m}^{3}$ ve poisson oranı (v) da 0,33 olarak hesaplanmıştır [10].

Saha çalışmaları sırasında kaya orta boyutlu olarak sınıflandırılmış ve çatlak pürüzlülük değeri $\left(\mathrm{J}_{\mathrm{r}}\right) 3$ ile 10 arasında değiştiği raporlanmıştır. 
Eş.(2) ve Eş.(3) yardımıyla yapısal özellik puanı (SR) ve süreksizlik yüzey koşulu puanı (SCR) hesaplanır:

$S R=-17,5 \times \ln \left(J_{v}\right)+79,8$

$\mathrm{SCR}=\mathrm{R}_{\mathrm{r}}+\mathrm{R}_{\mathrm{w}}+\mathrm{R}_{\mathrm{f}}$

Eş.(3)'de yer alan pürüzlülük puanı $\left(\mathrm{R}_{\mathrm{r}}\right)$ 5, bozunma puanı $\left(R_{w}\right) 5$ ve dolgu puanı $\left(R_{f}\right) 3$ olarak saha gözlemleri ile belirlenmiştir. $\mathrm{Bu}$ durumda süreksizlik yüzey koşulu puanı (SCR) 13 olarak hesaplanır. Eş.(2)'de tanımlanan JV değerinin belirlenmesi için sondaj çalışmaları sonucunda elde edilen kaya kütlesi kalitesi (RQD) değerlerinin ortalaması alınmaktadır. Sondaj loglarına göre $\mathrm{RQD}_{\text {ort }}$ değeri 88'dir. Minimum ve maksimum RQD değerleri ve sahada yapılan gözlemler sonucunda $J_{v}$ değerleri bulunmaktadır. Elde edilen $\mathrm{J}_{\mathrm{v}}$ değerleri Eş.(2)'deki denklemde kullanılarak yapısal özellik puanı hesaplanmaktadır. Yapısal özellik puanı ve süreksizlik yüzey koşulu puanı ile Hoek (1994) [11] tarafından hazırlanmış olan modifiye edilmiş GSI sınıflama sistemi grafiği kullanılarak GSI değerleri hesaplanmıştır. $\mathrm{J}_{\mathrm{v}}=3$ iken GSI $=53, \mathrm{~J}_{\mathrm{v}}=30$ iken GSI = 32 olarak elde edilir. Hesaplanan GSI değerleri yardımıyla kaya kütlesi sabiti olan $\mathrm{s}$ ve a değerleri Eş. (4) ve Eş. (5)'den hesaplanır. Bu eşitliklerde ki D, Jaeger ve Cook (1979) [12] tarafından geliştirilen kaya kütlesindeki örselenme derecesine bağlı bir sayı olup; bu çalışmada makine kazısı yapıldığ 1 için 0 ile 0,4 değerleri alınmıştır.

$\mathrm{S}=\exp \left(\frac{\mathrm{GSI}-100}{9-3 \times \mathrm{D}}\right)$

$\mathrm{a}=\frac{1}{2}+\frac{1}{6} \times\left(\mathrm{e}^{\frac{-\mathrm{GSI}}{15}}-\mathrm{e}^{\frac{-20}{3}}\right)$

Kaya kütlesinin $\mathrm{m}_{\mathrm{b}}$ sabiti ile GSI arasındaki ilişki Eş. (6)' de verilmiştir.

$\mathrm{m}_{\mathrm{b}}=\mathrm{m}_{\mathrm{i}} \times \exp \left(\frac{\mathrm{GSI}-100}{28-14 \times \mathrm{D}}\right)$

Eş.(8)'de $\mathrm{m}_{\mathrm{b}}, \mathrm{m}_{\mathrm{i}}$ kaya malzemesi katsayısının indirgenmiş değeri ve $\mathrm{m}_{\mathrm{i}}$, kaya türüne bağlı olarak değişen bir sabittir. Eş. $(4-6)$ yardımıyla hesaplanan $\mathrm{s}$, a ve $\mathrm{m}_{\mathrm{b}}$ değerleri Tablo 2'de verilmektedir.

İçsel sürtünme açısı ve kohezyon değerlerini hesaplayabilmek amaciyla öncelikle s3n' değerinin hesaplanması gerekmektedir [13].

$\frac{\sigma_{3 \max ^{\prime}}}{\sigma_{\mathrm{cm}}{ }^{\prime}}=0,47 \times\left(\frac{\sigma_{\mathrm{cm}}{ }^{\prime}}{\gamma \times \mathrm{H}}\right)^{-0,94}$
Tablo 2. a, s ve mb parametrelerinin değişimi (a,s, and $\mathrm{m}_{\mathrm{b}}$ parameter values)

\begin{tabular}{|l|c|c|c|}
\hline & $\mathrm{a}$ & $\mathrm{s}$ & $\mathrm{m}_{\mathrm{b}}$ \\
\hline $\begin{array}{l}\text { MinimumGSI- } \\
\text { Minimum } \sigma_{\mathrm{ci}}\end{array}$ & 0,520 & 0,0005 & 2,380 \\
\hline $\begin{array}{l}\text { Maksimum GSI- } \\
\text { Minimum } \sigma_{\mathrm{ci}}\end{array}$ & 0,505 & 0,0054 & 5,039 \\
\hline $\begin{array}{l}\text { MinimumGSI- } \\
\text { Maksimum } \sigma_{\mathrm{ci}}\end{array}$ & 0,520 & 0,0005 & 2,090 \\
\hline $\begin{array}{l}\text { MaksimumGSI- } \\
\text { Maksimum } \sigma_{\mathrm{ci}}\end{array}$ & 0,505 & 0,0024 & 4,048 \\
\hline
\end{tabular}

Eş. (7)'de verilen değerlerden $\sigma_{3 \max }$ ', HoekBrown ve Mohr-Coulomb kriterleri arasındaki ilişkinin göz önüne alındığı yanal gerilmenin üst sınır değeri ve $\sigma_{\mathrm{cm}}$ ' kaya kütlesi dayanımı değeridir. İçsel sürtünme açısı $(\phi)$ değerinin hesaplaması için Eş.(8), kohezyon (c) değerinin hesaplanması içinde Eş.(9) kullanılmaktadır.

$\phi=\sin ^{-1}\left[\frac{6 \times a \times m_{b} \times\left(s+m_{b} \times \sigma_{3 n^{\prime}}\right)^{a-1}}{2 \times(1+a) \times(2+a)+6 \times a \times m_{b} \times\left(s+m_{b} \times \sigma_{3 n^{\prime}}\right)^{a-1}}\right]$

$c^{\prime}=\frac{\sigma_{\mathrm{ci}} \times\left[(1+2 \mathrm{a}) \times \mathrm{s}+(1-\mathrm{a}) \times \mathrm{m}_{\mathrm{b}} \times \sigma_{3 n^{\prime}}\right] \times\left(s+\mathrm{m}_{\mathrm{b}} \times \sigma_{3 n^{\prime}}\right)^{\mathrm{a}-1}}{(1+\mathrm{a}) \times(2+\mathrm{a}) \times \sqrt{\frac{1+\left(6 \times \mathrm{a} \times \mathrm{m}_{\mathrm{b}} \times\left(s+\mathrm{m}_{\mathrm{b}} \times \sigma_{\left.3 \mathrm{n}^{\prime}\right)^{\mathrm{a}-1}}\right.\right.}{(1+\mathrm{a}) \times(2+\mathrm{a})}}}$

(9)

Elastitisite modülünü hesaplamak içinde Hoek tarafından geliştirilen denklem kullanılmaktadır [14]:

$$
\begin{aligned}
& \mathrm{E}_{\mathrm{M}}(\mathrm{GPa})= \\
& \left(1-\frac{\mathrm{D}}{2}\right) \sqrt{\frac{\sigma_{\mathrm{ci}}(\mathrm{MPa})}{100}} \times 10^{\frac{\mathrm{GSI}-10}{40}} \quad \sigma_{\mathrm{ci}} \leq 100 \mathrm{MPa}
\end{aligned}
$$

$\mathrm{R}_{\mathrm{f}}$ değerleri için ise literatürde kullanılan değerlerden yararlanılmıştır [15]. Hesaplamalar sonucunda bulunan değerlerin tamamı minimum (1.Küme) ve maksimum (2.Küme) olarak iki küme halinde Tablo 3'de gösterilmektedir. Her bir kümede yer alan parametreler arazi ve laboratuvar deney sonuçları, uç değerler ve literatür bilgisi kullanılarak oluşturulmuştur. 
Tablo 3. Hesaplanan $\mathrm{m}_{\mathrm{i}}, \sigma_{\mathrm{c}}, \mathrm{D}$, GSI, $\mathrm{E}_{\mathrm{m}}, \mathrm{R}_{\mathrm{f}}, \phi$ ve c değerleri (Calculated $\mathrm{m}_{\mathrm{i}}, \sigma_{\mathrm{ci}}, \mathrm{D}, \mathrm{GSI}, \mathrm{E}_{\mathrm{m}}, \mathrm{R}_{\mathrm{f}}, \phi$ and $\mathrm{c}$ values)

\begin{tabular}{|c|c|c|c|c|c|c|c|c|c|}
\hline $\begin{array}{c}\text { Parametr } \\
\text { eler }\end{array}$ & $\mathrm{m}_{\mathrm{i}}$ & $\begin{array}{c}\sigma_{\mathrm{ci}} \\
(\mathrm{MPa})\end{array}$ & $\mathrm{D}$ & $\mathrm{GSI}$ & $\phi\left(^{\circ}\right)$ & $\begin{array}{c}\mathrm{c} \\
(\mathrm{kPa})\end{array}$ & $\begin{array}{c}\mathrm{E}_{\mathrm{m}} \\
(\mathrm{GPa})\end{array}$ & $\begin{array}{c}\mathrm{R}_{\mathrm{f}} \\
\text { Tepe }\end{array}$ & $\begin{array}{c}\mathrm{R}_{\mathrm{f}} \\
\text { Yanal }\end{array}$ \\
\hline 1.Küme & 27 & 20,8 & $0-0,4$ & $32-53$ & $52,9-58,42$ & $191-291$ & $0,556-2,196$ & $0,4-0,6$ & $0,3-0,6$ \\
\hline 2.Küme & 30 & 67,54 & $0-0,4$ & $32-53$ & $61,93-61,10$ & $311-442$ & $7,31-9,107$ & $0,3-0,5$ & $0,2-0,4$ \\
\hline
\end{tabular}

parametre için oluşturulan kombinasyonların ilk 8

\subsection{Rastgele Küme Sonlu Elemanlar Metodu}

\section{(Random Set Finite Element Method)}

Rastgele küme sonlu elemanlar metodunun geoteknik tasarım üzerinde uygulanması aşağıdaki adımları içermektedir. İlk aşamada geoteknik davranışın belirlenmesi amacıyla geometri tanımlanmalı ve hesap modeli seçilmelidir. Hesap modeli, limit denge analizi, nümerik veya analitik çözüm, sonlu elemanlar/farklar yöntemlerinden birisi olabilir. Sonlu elemanlar veya farklar yönteminde kayayı ve destek elemanlarını temsil edecek bünye modeli belirlenir. Seçilen hesap modeline ait girdi parametreleri saptanır. Model davranışını etkileyen girdi parametrelerinin seçilmesi hassasiyet analizi gibi yöntemler yardımıyla hedeflenir [6]. Zeminlerin mekansal değişkenliği birçok araştırmacı tarafindan çalışılan bir konu olup; varyans azaltma gibi bir teknikle kaya parametrelerine mekansal korelasyon uzunluğu tanımlanmalıdır. Zeminin mekansal değişkenliği ile ilgili olarak Vanmarcke (1983) [16], Griffiths and Fenton (2000) [17], Lacasse and Nadim (1996) [18], Gören ve ark., (2013) [19] yaptıkları çalışmalar örnek verilebilir. Seçilen parametrelerin alt ve üst değerleri kullanılarak girdi setleri hazırlanır. Girdi setindeki değişken sayısı $\mathrm{n}$ ile gösterilecek olursa analiz sayısı $2^{\mathrm{n}}$ adet olacaktır. Son aşamada ise elde edilen girdi setleri kullanılarak deterministik sonlu elemanlar hesaplamalarının yapılması yer alır.

Rastgele küme sonlu elemanlar yönteminde parametrelere bağlı olarak analiz kombinasyon sayısı $\left(\mathrm{n}_{\mathrm{c}}\right)$ aşağıdaki gibi belirlenir:

$\mathrm{n}_{\mathrm{c}}=2^{\mathrm{N}} \prod_{\mathrm{i}=1}^{\mathrm{N}} \mathrm{n}_{\mathrm{i}}$

Eş. (11)'de $\mathrm{n}_{\mathrm{i}}$ : bilgi kaynağı sayısı, $\mathrm{N}$ ise değişken sayısını ifade etmektedir. Model girdi parametreleri elastisite modülü, kohezyon, içsel sürtünme açısı ve rahatlama faktörüdür. Her bir parametre için bilgi kaynağ 2 tanedir. Bu durumda $n_{c}=2^{4} \times 2^{4}=256$ adet analiz kombinasyonu oluşmuştur. Dört tanesi Tablo 4'de gösterilmektedir. Tablo 4'de değerlerin aşağıdan yukarıya gösterim sırası $R_{f}, \phi$, c ve E şeklindedir.

Kombinasyonlarda bulunan her bir parametre en yüksek ve en düşük olmak üzere 2 değer almaktadır. En düşük ve en yüksek değerin gerçekleşme olasılılıklarının eşit olduğu kabul edilmiştir. $\mathrm{Bu}$ durumda her kümenin gerçekleşme olasılığı 0,5 olmaktadır. Örneğin Eş.(12)' de yer alan her parametrenin gerçekleşme olasilığ 0,5 olduğundan, analiz kombinasyonunun olasıllığ 0,0625 olarak elde edilir.

$p\left(f\left(E_{1}, c_{1}, \phi_{1}, R_{1},\right)\right)=p\left(E_{1}\right) p\left(c_{1}\right) p\left(\phi_{1}\right) p\left(R_{1}\right)=$ $0,5 \times 0,5 \times 0,5 \times 0,5=0,0625$

Tablo 4. 4 değişken değer için oluşturulan ilk 8 kombinasyon (The first 8 combinations created for 4 variable values )

\begin{tabular}{|c|c|c|c|c|c|c|c|c|c|c|}
\hline \multicolumn{11}{|c|}{$\mathrm{E}_{1}, \mathrm{c}_{1}, \phi_{1}, \mathrm{R}_{\mathrm{fl}}$} \\
\hline \multicolumn{3}{|c|}{$\begin{array}{l}\text { Deneme } \\
\text { No. }\end{array}$} & 1 & 2 & 3 & 4 & 5 & 6 & 7 & 8 \\
\hline $\begin{array}{l}\overline{\mathbb{d}} \\
\frac{0}{\Sigma}\end{array}$ & $\begin{array}{l}\frac{y}{7} \\
\overrightarrow{0} \\
\frac{a}{0}\end{array}$ & $\left|\begin{array}{c}\dot{0} \\
z \\
\dot{0} \\
\tilde{c}\end{array}\right|$ & $\hat{\widehat{\hat{ि}}}$ & 会 & 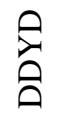 & 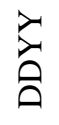 & 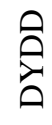 & 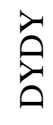 & 完 & $\begin{array}{l}\lambda \\
\bar{\partial} \\
0\end{array}$ \\
\hline \multirow{4}{*}{$\mid \begin{array}{l}\infty \\
1 \\
-1\end{array}$} & $n$ & -1 & $\begin{array}{l}0 \\
n \\
n \\
0\end{array}$ & $\stackrel{\circ}{\stackrel{1}{i}}$ & $\begin{array}{l}0 \\
n \\
n \\
0\end{array}$ & $\stackrel{\circ}{\stackrel{2}{i}}$ & $\begin{array}{l}0 \\
n \\
n \\
0\end{array}$ & $\frac{2}{i}$ & $\begin{array}{l}0 \\
n \\
n \\
o\end{array}$ & $\stackrel{\circ}{\stackrel{2}{i}}$ \\
\hline & $\tilde{n}$ & - & $\bar{a}$ & $\bar{a}$ & $\overline{\grave{\lambda}}$ & $\overline{\mathrm{\lambda}}$ & $\bar{a}$ & $\bar{a}$ & $\bar{\AA}$ & $\overline{\mathrm{i}}$ \\
\hline & $n$ & -1 & $\begin{array}{l}\overrightarrow{\widehat{\hat{n}}} \\
\hat{n}\end{array}$ & $\begin{array}{l}\vec{a} \\
\hat{n}\end{array}$ & $\begin{array}{l}\overline{\widehat{i}} \\
\hat{n}\end{array}$ & $\begin{array}{l}\bar{\sigma} \\
\text { nิ }\end{array}$ & $\begin{array}{l}\text { f } \\
\text { in } \\
\text { in }\end{array}$ & $\begin{array}{l}\mathcal{F} \\
\text { f } \\
i n\end{array}$ & $\begin{array}{l}\text { I } \\
\text { s } \\
i n\end{array}$ & $\begin{array}{l}\text { I } \\
\text { in } \\
\text { in }\end{array}$ \\
\hline & $n$ & -1 & 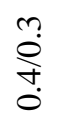 & 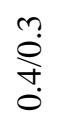 & 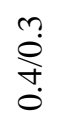 & 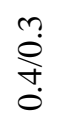 & $\stackrel{\text { m}}{\stackrel{m}{+}}$ & 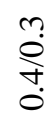 & 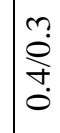 & 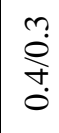 \\
\hline & & & E & & & & & & & \\
\hline
\end{tabular}




\subsection{Sonlu Elemanlar Modeli (Finite Element Model)}

Analizler içn Phase2 v8.0 sonlu elemanlar yazılımı kullanılmıştır. Kaya bünye modeli MohrCoulomb olarak seçilmiştir. Tünel destekleme elemanları elastik olarak modellenmiştir. Sonlu elemanlar ağı 2 boyutlu geometri ile yaklaşık 5000 elemandan oluşan 6 düğüm noktalı üçgen elemanlar ile tanımlanmıştır.

Kulhawy (1974) [20] çalışmasında sı̆̆ tünel olarak kabul edilen tünellerde dış sınır mesafeleri çapının 6 katı olarak modellenmesi gerektiğini söylemiştir. Ayrıca derinliği çapının 5 katını geçmeyen tüneller sığ tünel kabul ederken, derinliği çapının 10 katından fazla olan tüneller ise derin tünel olarak kabul etmektedir [20]. Bu çalışmada tünel sı̆̆ tünel olarak alınmıştır. Sı ğ tünel için sınır koşulları üst bölgede yerçekimi etkisinde gerilme durumunu değerlendirmeye alırken, yan kenarlarda yatay yer değiştirmelere kapalı, alt kenarlarda ise hem yatay hem de düşey yer değiștirmelere kapalı olacak şekilde sınır koşullar tanımlanmıştır (Şekil 5).

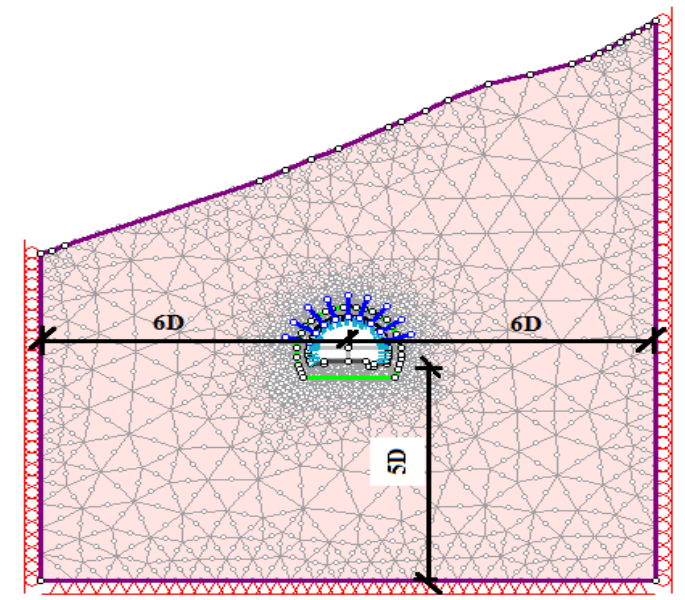

Şekil 5. Sı ̆̆ tünel model sınırları ve şartları (Model limits and boundary conditions of shallow tunnel)

\subsubsection{Rahatlama faktörü değerinin modele}

tanımlanması (Definition of relaxation factor value in the model)

Rahatlama faktörü, 2 boyutlu olarak hazırlanmış analizlerde 3 . boyut etkisinin modele yansitılmasinı sağlamaktadır. Rahatlama faktörünün hesaplanması için plastik bölgenin belirlenmesi gerekmektedir. Plastik bölge tünelde destek elemanları olmaksızın oluşan deformasyonun oluştuğu yerin tünel merkez noktasına uzaklığıdır. Yapılan analizler neticesinde de Şekil 6'da plastik bölge yarıçap1 $\left(R_{p}\right)$ 7,1 metre olarak hesaplanmıştır.
Tünel yarıçap1 $\left(\mathrm{R}_{\mathrm{t}}\right)$ 4,00 metredir. $\mathrm{Bu}$ durumda plastik bölge yarıçapının tünel yarıçapına oranı $\left(R_{p} /\right.$ $\mathrm{R}_{\mathrm{t}}$ ) 1,79'dur. Tünel yüzünden ilerleme mesafesi $2 \mathrm{~m}$ olarak analizlerde alınırsa tünel yüzünden ilerlenen mesafenin tünel yarıçapına oranı $2 / 4=0,5$ elde edilir.

Bulunan değerler Vlachopoulos ve Diederichs [21] tarafından geliştirilen Şekil 7'deki diyagramda yerlerine konulduğunda kapanma / maksimum kapanma değeri 0,58 olarak okunmaktadır. Sonlu elemanlar analizinden tünel arının 2 metre kazılması durumunda maksimum deformasyon 0,002 metre olmaktadır. Destekleme sistemi olmaksızın tünel çatısı $0,58 \times 0,002=1,2 \mathrm{~mm}$ deformasyon yapacaktır. Maksimum deformasyon, içsel basıncın artan değerlerine göre aşamalandırılır. Bu durumda 1,2 mm deformasyona karşılık gelen kazı aşaması belirlenir (Şekil 8). Bu değer uygulanması gereken kazı aşaması sayısını vermektedir.

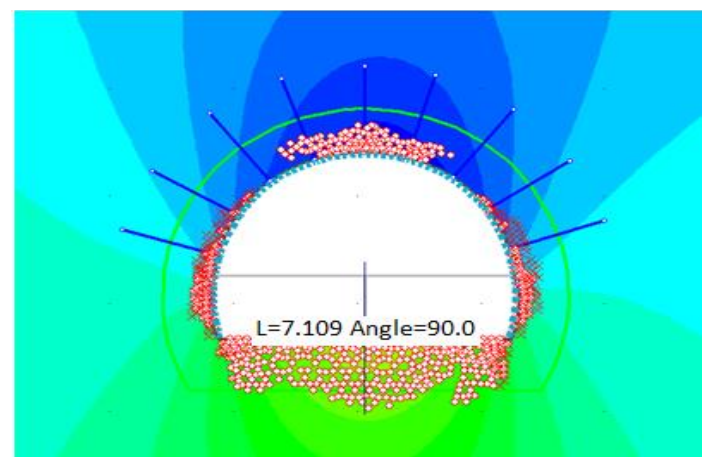

Şekil 6. Düşey deformasyon ile plastik bölgenin belirlenmesi (Determination of plastic zone by vertical deformation)

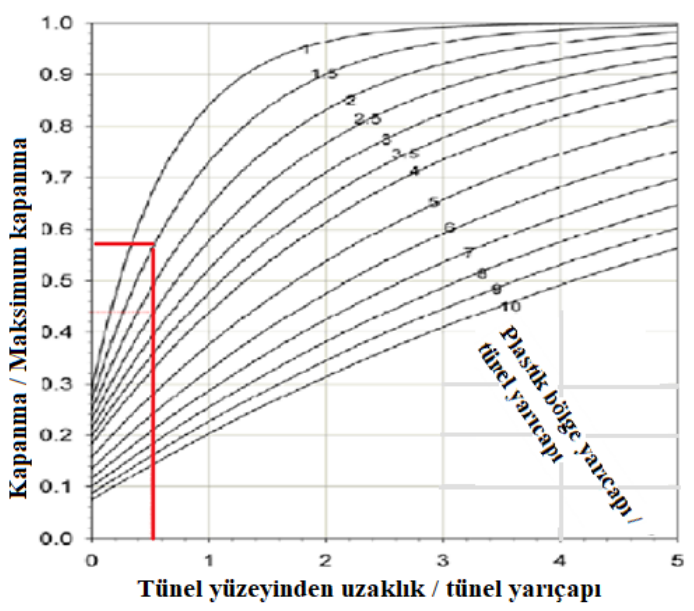

Şekil 7. Kapanma / Maksimum kapanma ile tünel yüzeyinden uzaklık / tünel yarıçapı korelasyonu (Correlation of closure / maximum closure and distance / tunnel radius from the tunnel surface ) 


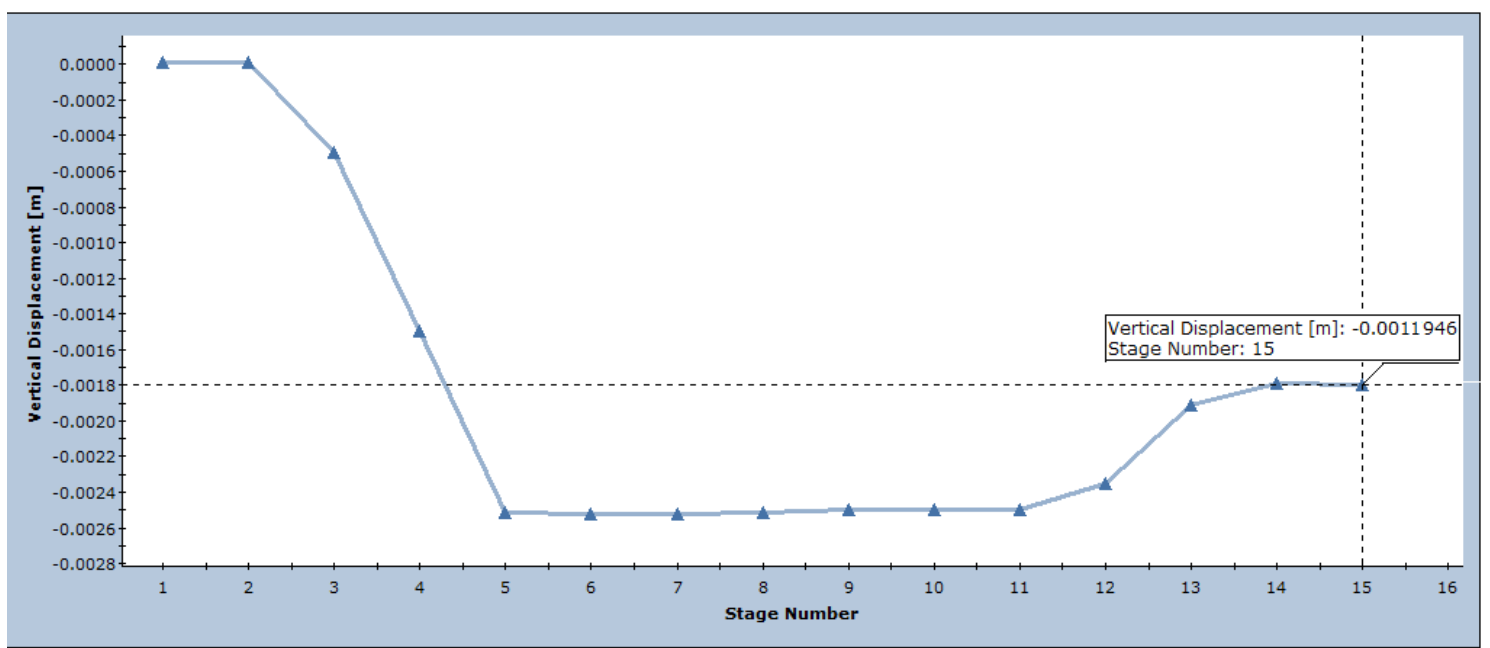

Şekil 8. Maksimum deformasyon ile kazı aşamasının belirlenmesi ( Determination of the excavation phase with maximum deformation)

Rahatlama faktörü hem alt yarıda hem de üst yarıda 1 'den 0 'a kadar azalan değerler almaktadır. Kazı öncesi durumu göstermek amacıyla 1 değeri alınırken kazı sonrası durum için 0 değeri kullanılmaktadır (Tablo 5). Bu iki değer arasında kalan durumlar içinde Schweiger, H.F. Nasekhian, A. ve Marcher, T. (2011) yapmış olduğu çalışma sonucunda bulunan değerler kullanılmaktadır [15]. Analizler sonucunda modelde kullanılması gereken kazı aşaması 15 olarak elde edilir.

Tablo 5. Tünel bölgesine göre rahatlama faktörü değerleri (Relaxation factor values for tunnel sections)

\begin{tabular}{|c|c|c|c|}
\hline $\begin{array}{c}\text { Aşam } \\
\mathrm{a}\end{array}$ & $\begin{array}{c}\text { Üst Yarı } \\
\mathrm{R}_{\mathrm{f}}\end{array}$ & $\begin{array}{c}\text { Sol Alt Yarı } \\
\mathrm{R}_{\mathrm{f}}\end{array}$ & $\begin{array}{c}\text { Să̆ Alt Yarı } \\
\mathrm{R}_{\mathrm{f}}\end{array}$ \\
\hline 1 & 0 & 0 & 0 \\
\hline 2 & 1 & 1 & 1 \\
\hline 3 & 0,8 & 1 & 1 \\
\hline 4 & $0,4 / 0,6$ & 1 & 1 \\
\hline 5 & 0 & 1 & 1 \\
\hline 6 & 0 & 1 & 1 \\
\hline 7 & 0 & 1 & 1 \\
\hline 8 & 0 & 0,8 & 1 \\
\hline 9 & 0 & $0,3 / 0,5$ & 1 \\
\hline 10 & 0 & 0 & 1 \\
\hline 11 & 0 & 0 & 1 \\
\hline 12 & 0 & 0 & 0,8 \\
\hline 13 & 0 & 0 & $0,3 / 0,5$ \\
\hline 14 & 0 & 0 & 0 \\
\hline 15 & 0 & 0 & 0 \\
\hline
\end{tabular}

\subsubsection{Tünel kazı aşamaları (Tunnel excavation stages)}

Sonlu eleman metodu ile yapilacak analizlerde tünel kazı aşamalarının modele aktarılması, gerilme ve deformasyonları etkilemektedir. Çalışma konusu olan Topçam Tüneli'nde NATM (yeni Avusturya metodu) kazı yöntemi olarak uygulanmıştır.Kazı 15 aşamalı olarak modellenmiştir.1.aşama tünel kazısına başlamadan önce arazi koşullarını yansıtmaktadır (Şekil 9). 2.aşama ise üst yarı kazısı öncesi rahatlama faktörünün 1 olarak modele tanımlanması ve kazıya başlanmasıdır. 3., 4. ve 5.aşama yardımıyla rahatlama faktörü sıfir olana kadar azaltılarak üst yarının kazısı modellenmiştir. 6.aşamada üst yarının destek elemanları modelde aktif hale getirilmiştir. 7.aşama ise üst yarıya ait kaya bulonunun aktif hale getirilmesidir. 8., 9. ve 10.aşama yardımıyla da rahatlama faktörü sıfır olana kadar azaltılarak sol alt yarının kazısı modellenmiştir. 11.aşamada sol alt yarıy ait destekleme elemanları aktifleştirilmiştir.12., 13. ve 14.aşama ile rahatlama faktörü sıfır olan kadar azaltılarak sağ alt yarının kazısı modellenmiştir. 15. Aşamada ise sağ alt yarıya ait destekleme elemanları aktif hale getirilmiştir (Şekil 10). 


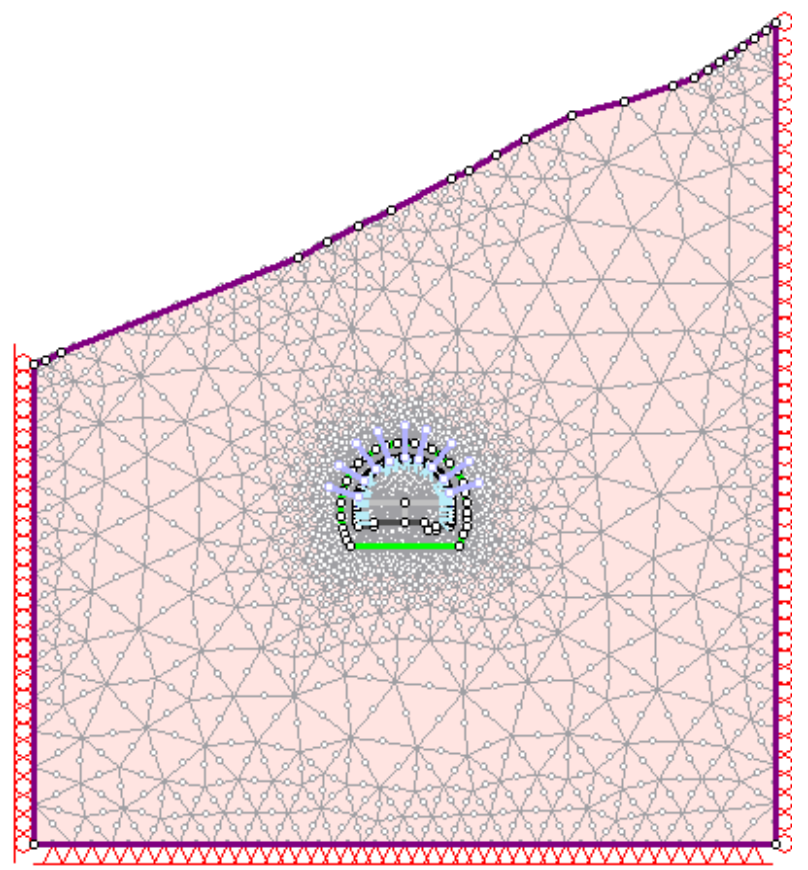

Şekil 9. Kazı öncesi tünel modeli (Tunnel model before excavation)

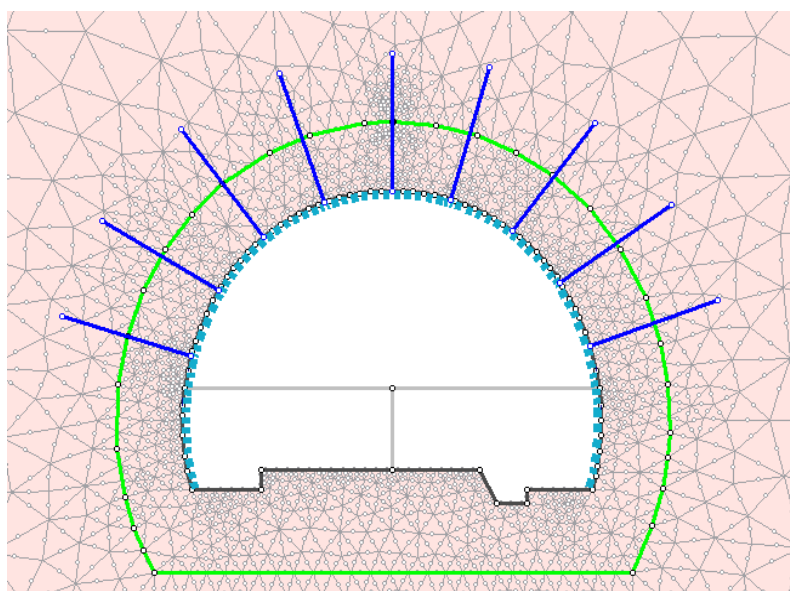

Şekil 10. Nihai tünel kazı aşaması (Final stage of tunnel excavation)

\subsection{Hesaplanan Deformasyonlar İçin Toplam}

\section{Olasılık Grafiklerinin Olușturulması ve}

Doğrulama (Creation and Validation of Total Probability Graphs for Calculated Deformations)

Analiz kombinasyonlarının her biri için sonlu elemanlar programında deformasyon analizi yapılmıştır. Arazi ölçümlerinden de elde edilen 5 noktaya ait düşey ve yatay deformasyonlar saptanmıştır. Hesaplanan ve ölçülen deformasyonların alt ve üst sınırları, yatay ve düşey durumlarına göre toplam olasılık grafiği 1 No'lu ölçüm noktası içinŞekil 11'de, 2 No'lu ölçüm noktası için Şekil 12'de verilmiştir.

Analiz kombinasyonlarında daha önceden belirlenen 4 parametreden $3^{\prime}$ ü sabit 1 parametre ise değişken alınarak hassasiyet analizi çalışması yapılmıştır. Elastisite modülü değişiminin deformasyon üzerindeki etkisi Şekil 13'de görülmektedir. Benzer şekilde hazırlanmış kohezyon, içsel sürtünme açısı ve $\mathrm{R}_{\mathrm{f}(\mathrm{Tepe})}$ değişkenlerinin deformasyon üzerinde önemleri 1, 2, 3, 4 No'lu deformasyon ölçüm noktalarına göre sırasıyla Şekil 14, Şekil 15 ve Şekil 16'da sunulmuştur.

\section{SONUÇLAR (CONCLUSIONS)}

Çalışmada Ordu ili, Ulubey ilçesine bağlı Topçam tüneli örneği üzerinde rastgele küme sonlu elemanlar metodu uygulanmış ve analizler 2 boyutlu sonlu eleman yazılımı ile yapılmıştır. Sonlu elemanlar yönteminde kullanılmak üzere elastisite modülü, kohezyon, içsel sürtünme açısı ve rahatlama faktörünün alt ve üst sınır değerleri $\sigma_{\text {ci }}$, GSI ve D'ye bağlı olarak hesaplanmıştır. Dört parametrenin hem alt ve üst sınır değerleri bulunduğundan toplamda sekiz değişken elde edilmiştir. Bu sekiz değer için aralarında kartezyen çarpım yapılarak 256 adet analiz kombinasyonunu oluşturulmuştur. Her bir kombinasyon için sonlu elemanlar yöntemi ile model oluşturularak deformasyon hesapları yapılmıştır. $\mathrm{Bu}$ hesaplamalar sonucunda deformasyon ve parametrelere bağlı olarak grafikler hazırlanmıştır. Şekil 13'de elastisite modülü ile deformasyon ilişkisi verilmiştir. $\mathrm{Bu}$ grafikte kayanın artan elastisite modülüne karşıllk yatay ve düşey deformasyonun azaldığ1 görülmüştür. Azalmanın en fazla olduğu nokta ise 1 noktası olup azalma $\% 90$ civarındadır. Kohezyon ile deformasyon ilişkisinin gösterildiği grafik olan Şekil 14 'de kohezyon değerinin artışına bağlı olarak yatay deformasyonun 1 ve 2 noktasında arttığı; 3,4 ve 5 noktalarında ise azaldı $\breve{g} 1$ görülmüştür. Bununla birlikte kohezyon artışı bütün noktaların düşey deformasyonlarında azalma oluşturmuştur. Şekil 15'deki içsel sürtünme açısı ile deformasyon grafiği incelendiğinde içsel sürtünme açısı artışının hem yatay hem de düşey deformasyonda 1 noktası hariç diğer noktalar için azaltma yaratmıştır. Ancak içsel sürtünme açısının artışı 1 noktasının yatay deformasyonunda bir değişime neden olmamış ve buna rağmen düşey deformasyonunda azalmaya neden olmuştur. Ayrıca içsel sürtünme açısının artışı en çok 3 noktasının deformasyonunu etkilemiş ve bu etki deformasyonda \%14 civarında bir değişim oluşturmuştur. Şekil 16'da 
$\mathrm{R}_{\mathrm{f}(\mathrm{Tepe})}$ ile deformasyon ilişkisi grafiği verilmiştir. $\mathrm{Bu}$ grafiğe göre de $R_{\mathrm{f}(\text { Tepe) }}$ değerinin artışı en fazla deformasyon değişimini 5 noktasında meydana getirmiştir. Buna rağmen $\mathrm{R}_{\mathrm{f}(\mathrm{Tepe})}$ değerinin artışı diğer noktalardaki deformasyonlarda azalmaya neden olmuş ve bu azalma \%5'i geçmemiştir. Karşılaştırmalarla beraber görülmüştür ki parametrelerin değişimi her nokta için farklı bir etki oluşturmuştur. $\mathrm{Bu}$ etki her bir noktanın yatay ve düşey deformasyonlarında da farklı şekilde olmuştur.

Çalışmada noktaların toplam olasılık değerleri ile saha ölçümlerindeki deformasyon ilişkisini ortaya koymak amacıyla Şekil 11 ve Şekil 12'deki grafikler hazırlanmıştır. Grafikte hesaplanan deformasyonların en yüksek ve en düşük değerlerini göstermek amacıyla iki küme halinde veriler bir araya getirilmiş ve ayrıca bu grafiklerde saha ölçümlerindeki değerlerde gösterilmiştir. Saha deformasyon ölçümlerindeki değerlerin, en düşük ve en yüksek deformasyon değerlerin oluşturduğu eğrilerin arasında kaldığı görülmüşsür.Sınır aralığında kalması da rastgele küme sonlu elemanlar yönteminin tünel deformasyonu hesabında uygulanabilirliğinin bir göstergesi olmuştur.

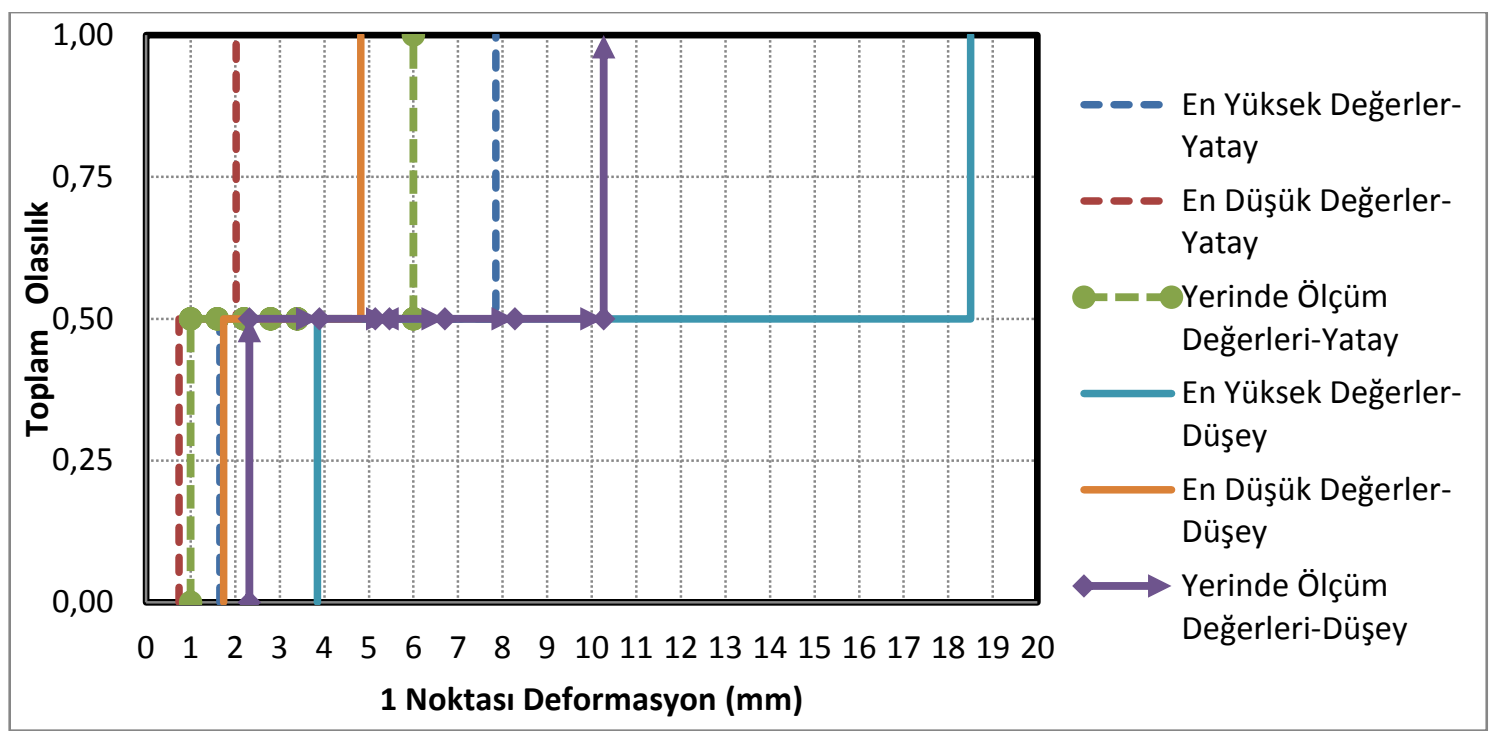

Şekil 11. 1 noktası için arazi ve hesaplanan deformasyon değerleri (In situ and calculated deformation values for Point \#1)

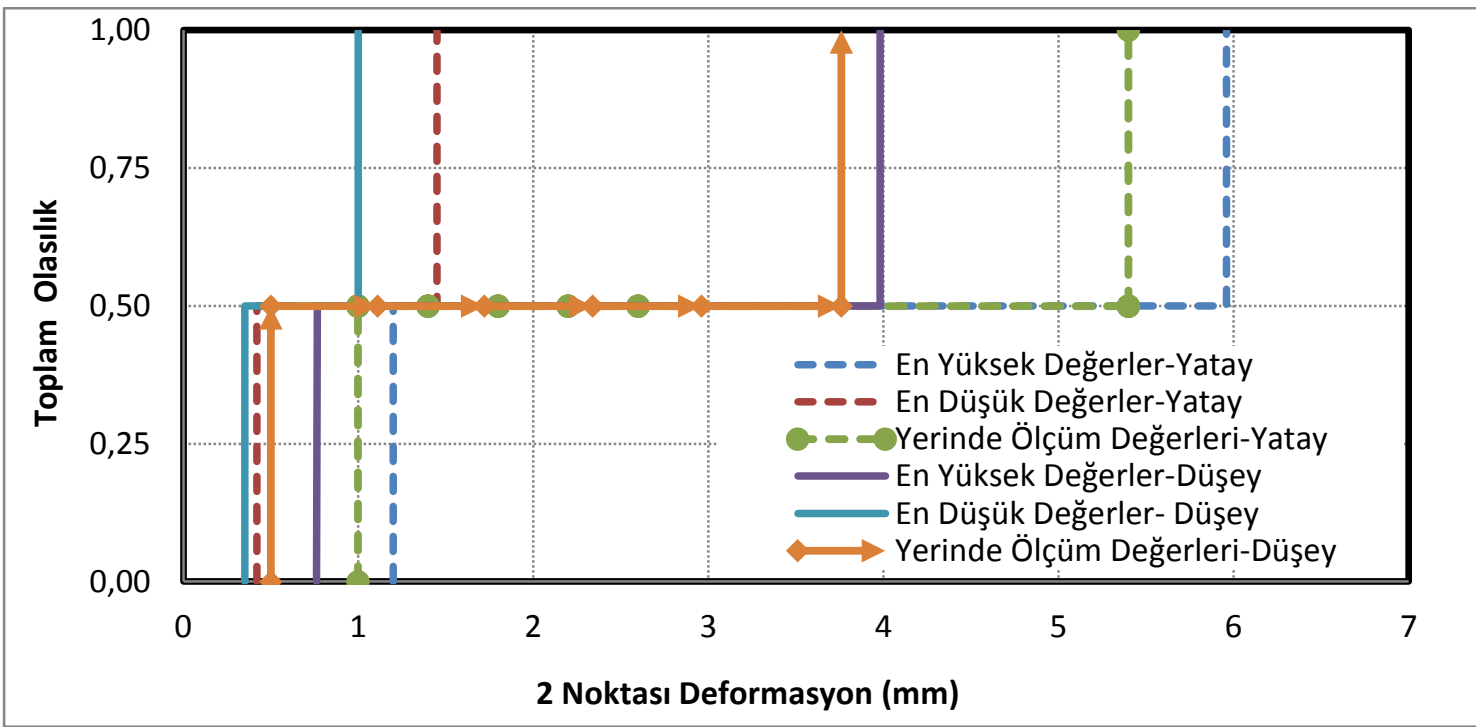

Şekil 12. 2 noktası için arazi ve hesaplanan deformasyon değerleri (In situ and calculated deformation values for Point \#2) 


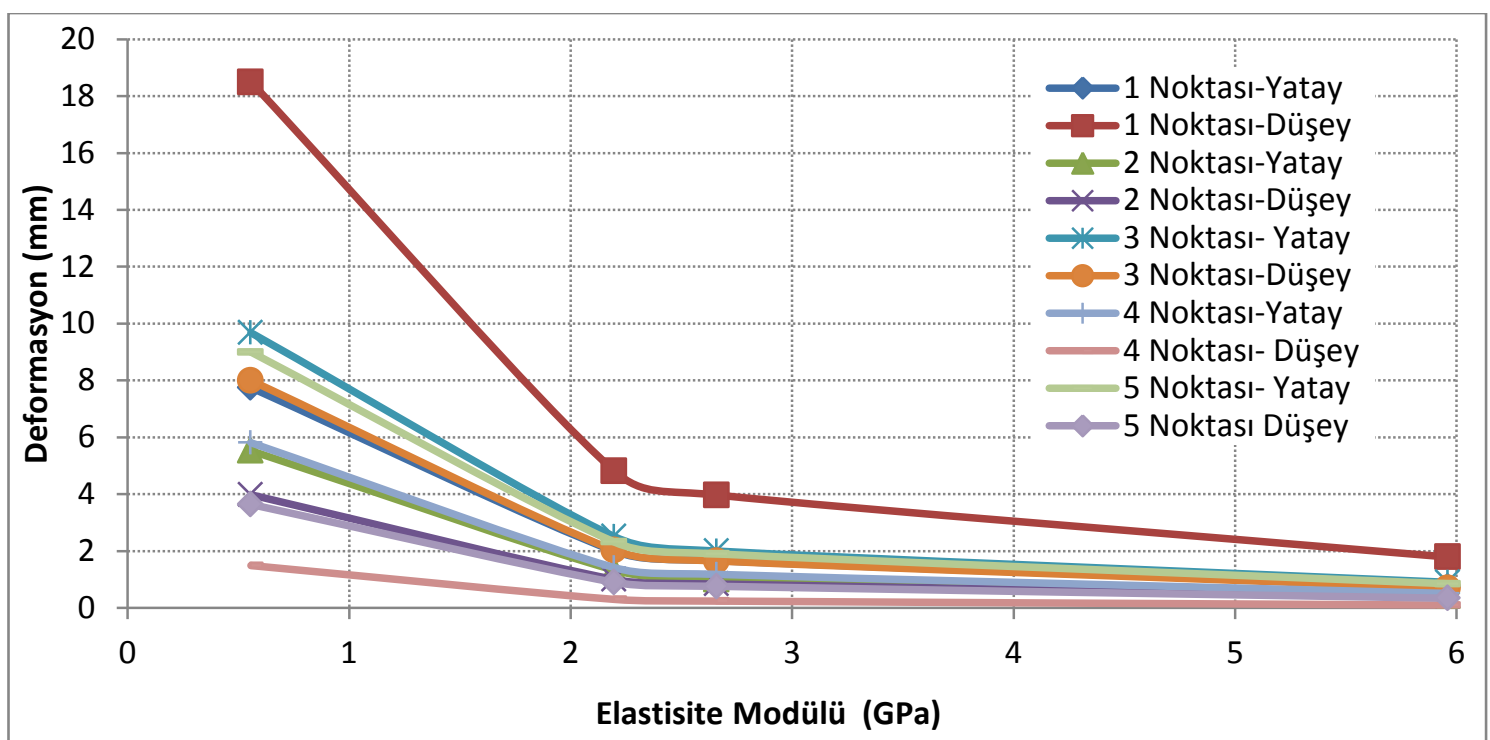

Şekil 13. Elastisite modülü değişiminin deformasyon üzerinde etkisi (Effect of varying elastic modulus on deformation)

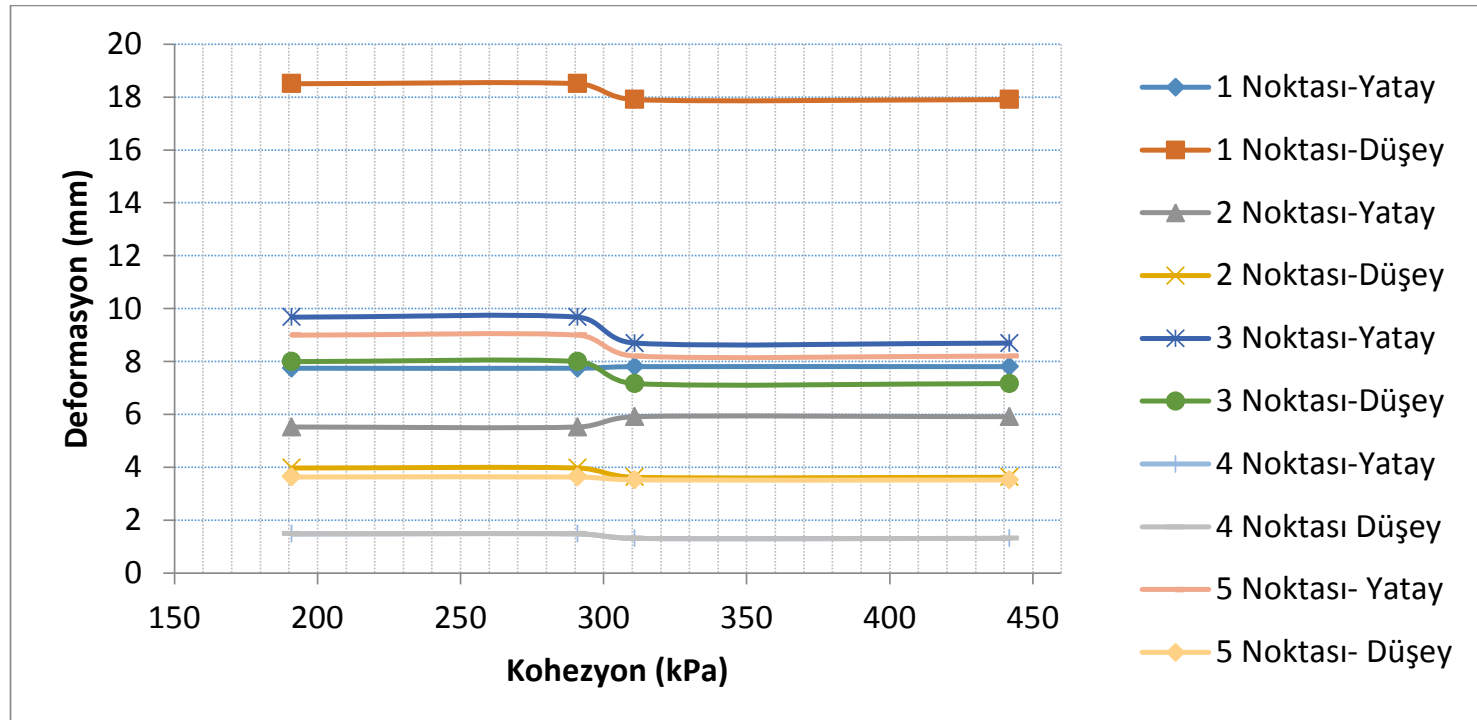

Şekil 14. Kohezyon değişiminin deformasyon üzerinde etkisi (Effect of varying cohesion on deformation) 


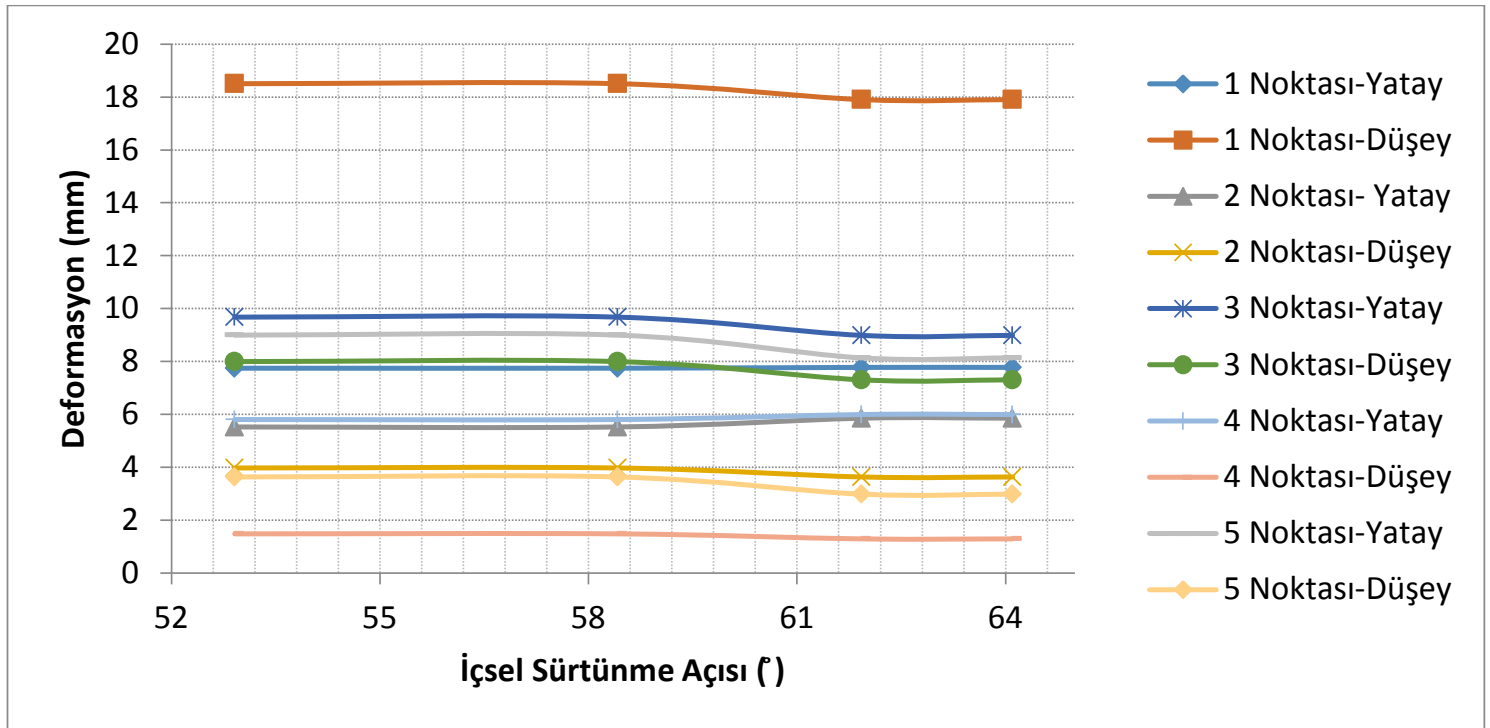

Şekil 15. İçsel sürtünme açısı değişiminin deformasyon üzerinde etkisi (Effect of varying internal friction angle on deformation)

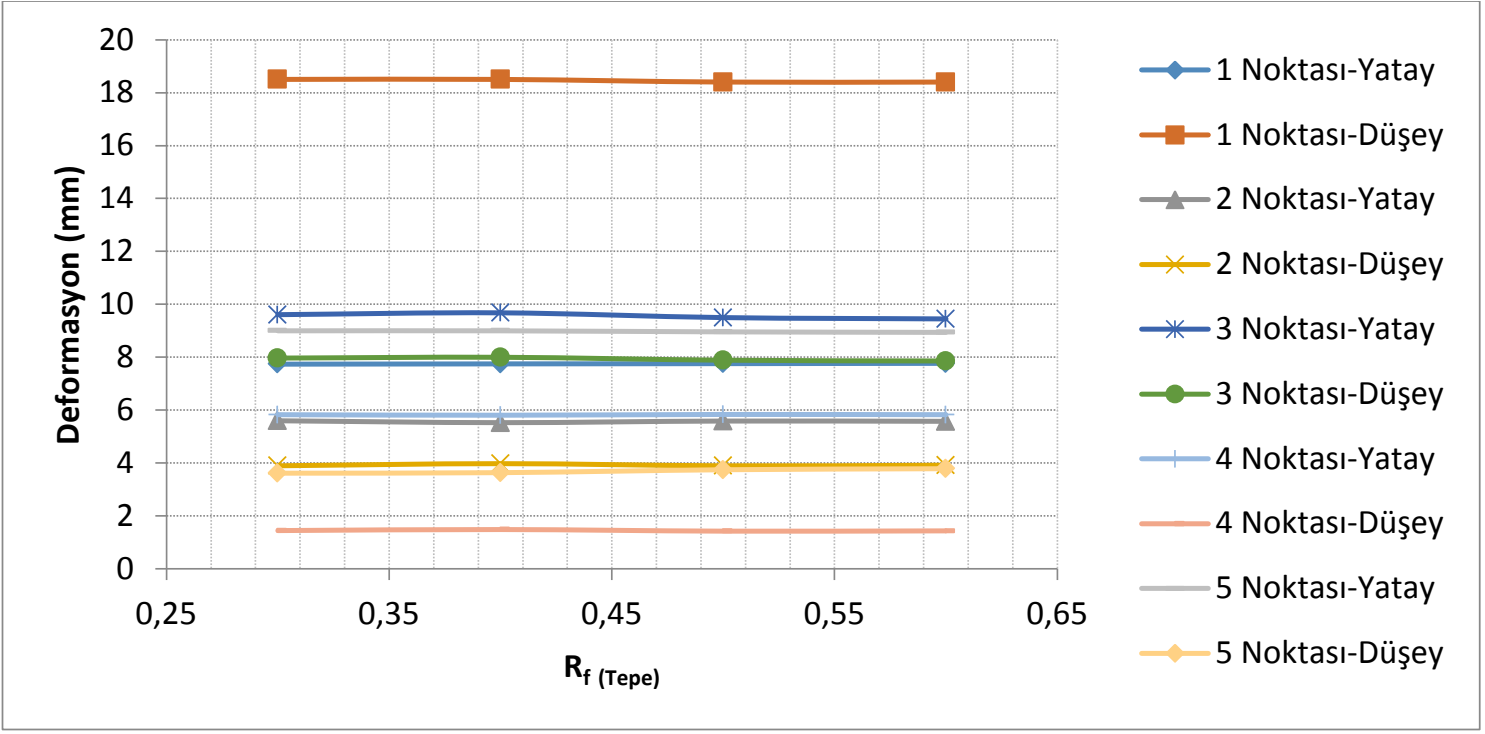

Şekil 16. $\mathrm{R}_{\mathrm{f}(\text { (Tepe) }}$ değişiminin deformasyon üzerinde etkisi (Effect of varying $\mathrm{R}_{\mathrm{f}(\mathrm{Tepe})}$ value on deformation)

\section{SIMGELER (SYMBOLS)}

D:Tünel çapı

c:Kohezyon

$\phi:$ İçsel sürtünme açısı

$\sigma_{1}:$ En büyük düzlemsel asal gerilme

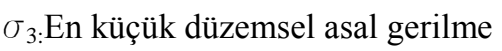

$\sigma_{\text {ci: }}$ Sağlam ve çatlaksız kaya malzemesinin tek eksenlibasınç dayanımı

E:Elastisite modülü

$\mathrm{E}_{\mathrm{M}}$ :Kaya kütlesi deformasyon modülü

$\mathrm{v}$ :Birim hacim ağırlık

$\mathrm{J}_{\mathrm{a}}:$ Eklem alterasyon sayıs 1

$\mathrm{J}_{\mathrm{n}}$ :Eklem takım sayıs1

$\mathrm{J}_{\mathrm{r}}$ :Eklem pürüzlülük sayısı
$\mathrm{J}_{\mathrm{w}}$ :Eklem su indirgeme faktörü

$\mathbf{J}_{\mathrm{v}}:$ Hacimsel eklem sayısiortalamas1

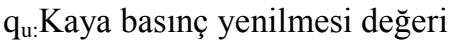

$\mathrm{m}_{\mathrm{b}}: \mathrm{m}_{\mathrm{i}}$ kaya malzemesi katsayısının indirgenmiş değeri

$\mathrm{m}_{\mathrm{i}}$ :Kaya türüne bağlı olarak değişen sabit

s:Kaya kütlesi sabiti

a:Kaya kütlesi sabiti

$v$ : Possion oranı

$\mathrm{R}_{\mathrm{r}}$ :Pürüzlülük puanı

$\mathrm{R}_{\mathrm{w}}$ :Bozunma puanı

$\mathrm{R}_{\mathrm{f}: \text { Dolgu puanı }}$ 


\section{KISALTMALAR (ACRONYMS)}

NATM:Yeni Avusturya Tünel Açma Metodu GSI: Jeolojik dayanım indeksi

SR: Yapısal özellik puanı

\section{KAYNAKLAR (REFERENCES)}

[1] K.K. Phoo and F.H. Kulhawy, "Characterization of geotechnical variability", Canadian Geotechnical Journal, vol. 36, pp. 612-624, 1999.

[2] A.P. Dempster, “ Upper and Lower probabilities induced by a multivalued mapping.", Annals of Mathematical Statistic, vol. 38, pp. 325-339, 1967.

[3] D.G. Kendall, “ Foundations of a theory of random sets.", In stochastic geometry, E.F. Harding and D.G. Kendall, Eds. New York, 1974.

[4] G. Shafer, "A Mathematical Theory of Evidence.", Princeton: Princeton University Press, 1976.

[5] D. Dubois and H. Prade, " Random sets and fuzzy interval analysis.”, Fuzzy Sets and Systems, vol. 42, pp. 87-101, 1991.

[6] G.M. Peschl, "Reliability Analysis in Geotechnics with the Random Set Element Method", Computers and Geotechnics, vol. 32, pp. 422-435, 2005.

[7] H.F. Schweiger, G.M. Peschl and R. Pöttler, “ Application of the random set finite element method for analysing tunnel excavation.", Georisk, vol. 1, pp. 43-56, 2007.

[8] Rocsicence "Phase2 2D finite element program for calculating stresses and estimating support around underground excavations user's guide", rocscience.com, 1998. [Online]. Avaiable: https://www.rocscience.com/downloads/phase2/Phas e2_TutorialManual. [Accessed: May. 7, 2019]

[9] W.Niemeier "Statistical tests for detecting movements in repeatedly measured geodetic Networks", Tectonophysics, vol. 71, pp. 335-351, 1981.

[10] "Ordu-Ulubey Ayrımı Topçam Tünelleri Jeolojik, Hidrojeolojik ve mühendislik jeolojisi etüt raporu", Emay Mühendislik, Ankara, Turkey, Tech. Report. 2013.
[11] E.Hoek, "Strength of rock and rock masses.", ISRM News Journal, vol. 2, pp. 4-16, 1994.

[12] J.C. Jaeger and N.G. Cook, "Fundamentals of rock mechanichs.", London: Chapman and Hall, 1979.

[13] E. Hoek, C. Carranza-Tores, and B. Corkum, "Hoek-Brown criterion", NARMS-TAC Conference, Toronto, 2002, vol. 1, pp. 267-273.

[14] E. Hoek and M. Diedreicks, "Empirical Estimation of Rock Mass Modulus.", International Journal of Rock Mechanics and Mining Sciences, vol. 43, pp. 203-215, 2006.

[15] H.F. Schweiger, A. Nasekhian and T. Marcher, "A comparison of random set and point estimate methods in finite element analysis of tunnel excavation.", Intenational Symposium On Geotechnical Safety and Risk, Germany, 2011. pp. 341-348.

[16] E.H. Vanmarcke, "Random fields analysis and synthesis.", Cambridge: MIT Press, 1983.

[17] D.V. Griffiths and G.A. Fenton, "Influence of soil strength spatial variability on the stability of an undrained clay slope by finite elements.", Proceeding of GeoDenver, 2000. pp. 184-193.

[18] S. Lacasse and F. Nadim, "Model uncertainty in pile axial capacity calculations.", Offshore Technology Conference, 1996. pp. 369-380.

[19] H. Gören, E. Tekin and S.O. Akbaş "Olasılıksal şev stabilitesi analizlerinde yerel değişkenliğin etkisi.", Taşkın ve Heyelan Sempozyumu, Trabzon, 2013. pp. 221-229.

[20] F.H. Kulhawy, "Finite element modelling criteria for underground openings in rock.", Mechanics and Mining Sciences and Geomechanics Abstracts, vol. 11, pp. 465-472, 1974.

[21] N. Vlachopoulos and M.S. Diederichs, “ Appropriate uses and pratical limitations of 2D numerical analysis of tunnels ans tunnel support response.", Geotechnical and Geological Engineering an International Journal, vol. 32, pp. 469-488, 2014. 


\section{Nail ÜNSAL}

Prof. Dr. Nail Ünsal, 1960 yılında Nevşehir'de doğdu. 1982 yılında Ankara Üniversitesi Mühendislik Fakültesinden mezun oldu. 1984 yılında yüksek lisansını, 1991 yılında doktorasını aynı üniversitede tamamladi. Gazi Üniversitesi Mühendislik-Mimarlık Fakültesi'nde 1991 yılında yardımcı doçent, 1997 yılında doçent ve 2003 yılında profesörlük ünvanını aldı. Ünsal'ın 35'in üzerinde yurtiçi ve yurtdışı bilimsel yayını bulunmaktadır. SCI indexte taranan dergilerde yayınlanan makalesiyle 1996

y1lında Erguvanlı Mühendislik Jeolojisi Ödülünü aldı. Ünsal, 2001-2004 yılları arasında Gazi Üniversitesi Mühendislik-Mimarlık Fakültesinde Dekan Yardımcılı̆̆ı ve 2008-2010 yılları arasında da Gazi Üniversitesi Fen Bilimleri Enstitüsü Müdürlüğü görevinde bulunmuştur. Prof. Dr. Ünsal 2010-2013 tarihleri arasında Gazi Üniversitesi Mühendislik Fakültesi Dekanlığını yapmıştır.

\section{Erhan TEKIN}

Gazi Üniversitesi Mühendislik Fakültesi İnşaat Mühendisliği Bölümü'nden lisans, yüksek lisans ve doktora derecelerini almıştır. Aynı bölümde 2002 yılında araştırma görevlisi olarak çalışmaya başlamış olan Dr. Tekin, 2012 yllında öğretim görevlisi kadrosunda aynı bölümde görevine devam etmektedir. Lisans seviyesinde zemin mekaniği, temel mühendisliği, yüksek lisans seviyesinde ise geoteknik sayısal modelleme derslerini vermektedir. İlgi alanları temellerin güvenilirliğe dayalı tasarımı, zemin yap1 etkileşimi ve sonlu elemanlar analizidir. Geoteknik etüt raporu, sığ/derin temel tasarımı, derin kazı, istinat duvarı, zemin iyileştirme, şev stabilitesi ve ıslahı konularında akademik danışmanlıkları bulunmaktadır.

\section{Gamze DÖNDER}

Gamze Dönder, 1989 yılında Ankara'da doğdu.2011 yılında Ondokuz Mayıs Üniversitesi Mühendislik Fakültesi İnşaat Mühendisliği Bölümü'nden mezun oldu. Gazi Üniversitesi Fen Bilimleri Enstütüsü İnşaat Mühendisliği (Mühendsilik Fakültesi) Anabilim Dalında yüksek lisans eğitimine devam etmektedir. 